\title{
Autoimmune hemolytic anemia IN Hodgkin's lymphoma: a case report
}

\begin{abstract}
Auto-immune hemolytic anemia (AIHA) has an extensive differential diagnosis though Hodgkin's lymphoma (HL) is not always an obvious diagnosis. AIHA can precede the diagnosis of HL for several years. In adults the association of AIHA and $\mathrm{HL}$ is more frequent in advanced stages of HL. Warm immune hemolytic anemia is mainly controlled with steroids and chemotherapy. We report a case of a patient with positive direct Coomb's test at the diagnosis of HL. This case reminds us that Hodgkin's lymphoma should be excluded in patients with hemolytic anemia or other auto-immune (like) manifestations.
\end{abstract}

Keywords: autoimmune haemolytic anemia, hodgkin's lymphoma, warm immune
Volume 4 Issue 6 - 2017

Samir S Shah, Shaila R Khubchandani, Rupali S Parikh, Lakshmi PVaswani

Pathology Department, Bhatia Hospital, India

Correspondence: Samir S Shah, Pathology Department, $2^{\text {nd }}$ Floor, Bhatia Hospital,Tukaram Jivaji Road, Tardeo, Mumbai 400007, India, Tel 022-66660643, Fax 022-66660032,

Email dr_samirshah@hotmail.com

Received: January 12, 2017 | Published: June 19, 2017
Abbreviations: AIHA, auto-immune hemolytic anemia; HL, Hodgkin's lymphoma; RS, reed sternberg; RA, rheumatoid arthritis; SS, sjögren syndrome; SLE, systemic lupus erythematous; DLBCL, diffuse large b-cell lymphoma

\section{Introduction}

AIHA is a recognized complication of lympho proliferative disorders. ${ }^{1}$ AIHA is rarely seen in HL patients with a reported incidence of $0.2-4.2 \%{ }^{2}$ Sporadic case reports and reviews have shown that when AIHA occurs in HL patients it happens mostly at stage III and IV of nodular sclerosis HL or mixed cellularity HL. ${ }^{2} \mathrm{HL}$ is usually manifested as lymphadenopathy typically in the cervical $(70 \%)$, axillary $(25 \%$,), mediastinal areas $(60 \%)$, and in $16-34 \%$ of the cases presents as nodal disease below the diaphragm. HL presenting as AIHA has been reported in very few case reports in literature. We hereby report a case HL who presented as AIHA. ${ }^{1}$

\section{Case report}

An 82 year old male patient with history of borderline diabetes since 12 years presented with on an off fever, malaise, generalized weakness, decreased appetite, weight loss, dizziness and itching all over the body since 1 month. There was history of hemiparesis, incontinence of urine and stool. On examination, his vital parameters were stable. Systemic examination revealed mild hepatomegaly and splenomegaly and bilateral basal crepitations on auscultation of the chest. He was found to have fever of $4{ }^{\circ} \mathrm{C}$ and pallor and right axillary lymphadenopathy which was non tender and rubbery to feel. Laboratory investigations for liver function tests revealed liver enzymes within normal ranges, with unconjugated hyperbilirubinemia (with total bilirubin of $2.9 \mathrm{mg} / \mathrm{dl}$ and indirect bilirubin of $1.6 \mathrm{mg} / \mathrm{dl}$ ). LDH was $910 \mathrm{U} / \mathrm{L}$. Iron studies were within normal ranges.

The complete blood count revealed Hemoglobin of $5.6 \mathrm{gm} /$ $\mathrm{dl}$, Hematocrit value $18.9 \%$, MCV 113fL, and $\mathrm{MCH} 33.5 \mathrm{pg}$ and reticulocyte count of $30 \%$. WBC count was 20,770 cells/cumm with $1 \%$ Promyelocytes, 4\% Myelocytes, 2\% Metamyelocytes, 3\% band cells, 66\% Neutrophils, 4\% Eosinophils, 17\% Lymphocytes, 3\% Monocytes. The peripheral smear examination showed moderate anisocytosis and poikilocytosis with spherocytes, polychromatic cells, Howell-Jolly bodies, Cabot rings, basophilic stippling and
70nRBCs/100 WBCs and mild RBC agglutination. The corrected WBC count was 12,217cells/cumm. Indirect and Direct Coomb's Test were strongly positive for $\mathrm{IgG}$ and $\mathrm{C} 3$. The reticulocyte count was $30 \%$. Hence, the diagnosis of AIHA was made. Serology for Mycoplasma pneumoniae was negative. His chest $\mathrm{X}$ ray was normal. Ultrasonography of the abdomen and pelvis revealed mild hepatomegaly upto $15.3 \mathrm{cms}$ with heterogeneous echotexture and mild splenomegaly of $12.5 \mathrm{cms}$. There were few simple cortical cysts in both the kidneys. Ultrasonography of right axilla showed multiple enlarged lymph nodes with maintained fatty hilum and increased vascularity. The largest lymph node was measuring $5.7 \mathrm{cmsX} 2.4 \mathrm{cms}$. There were no signs of necrosis or calcification. The right axillary lymph node was biopsied and submitted for histopathological examination. The biopsy showed polymorphous population of lymphocytes, plasma cells, eosinophils and scattered mononuclear and binuclear variants of Reed Sternberg (RS) cells. The immuno histochemistry on the lymph node biopsy revealed all the RS like cells stained strongly positively with CD 30 (membranes and Golgi). Few RS cells stain positively with CD 15. These cells stained negatively for CD45, CD 20 and Oct2.

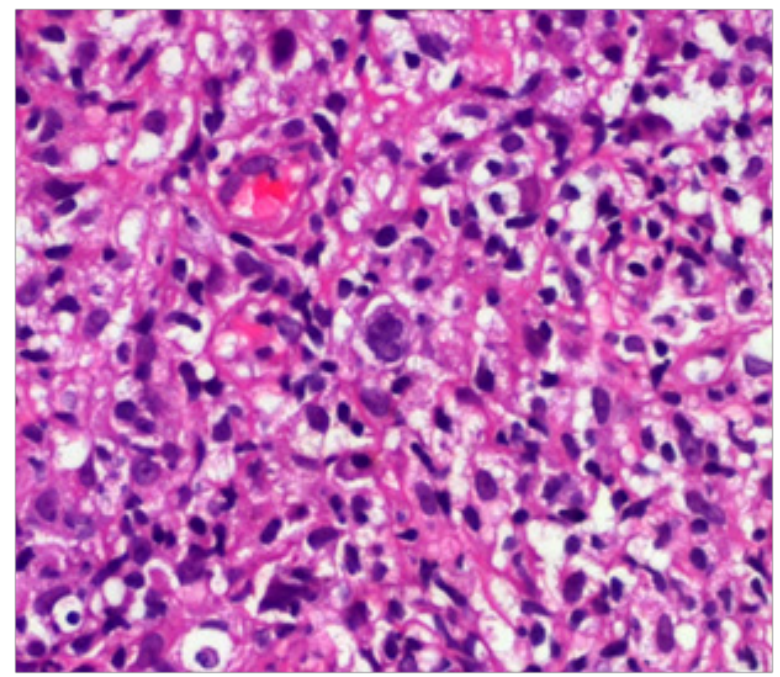

Figure I Photomicrograph of bone marrow biopsy showing Reed-Sternberg cells and its cellular environment. 


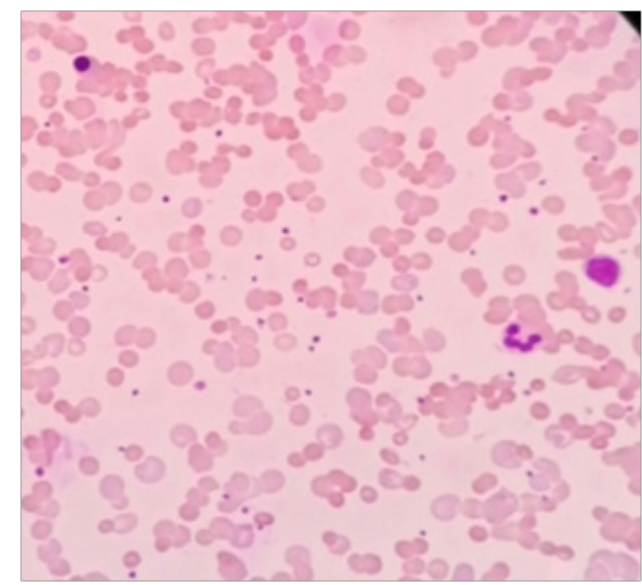

Figure 2 Photomicrograph of Leishman's stained peripheral blood smear showing spherocytes, RBC agglutination, nucleated RBCs, neutrophil and lymphocyte.

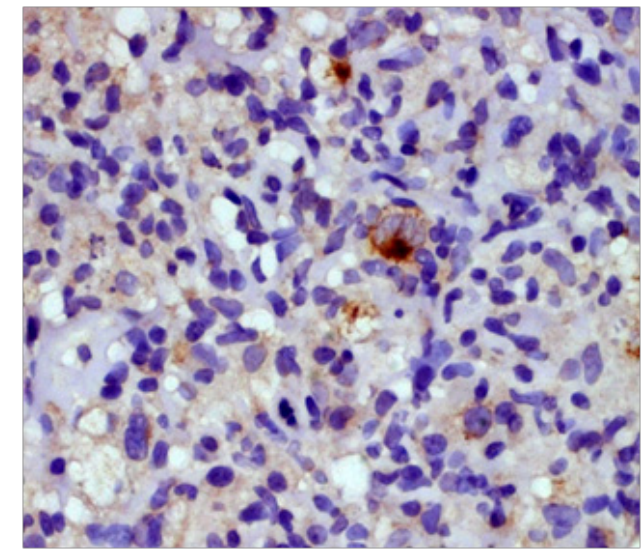

Figure 3 Photomicrograph showing Reed-Sternberg cells staining strongly positive for CD 30 (membranes and Golgi).

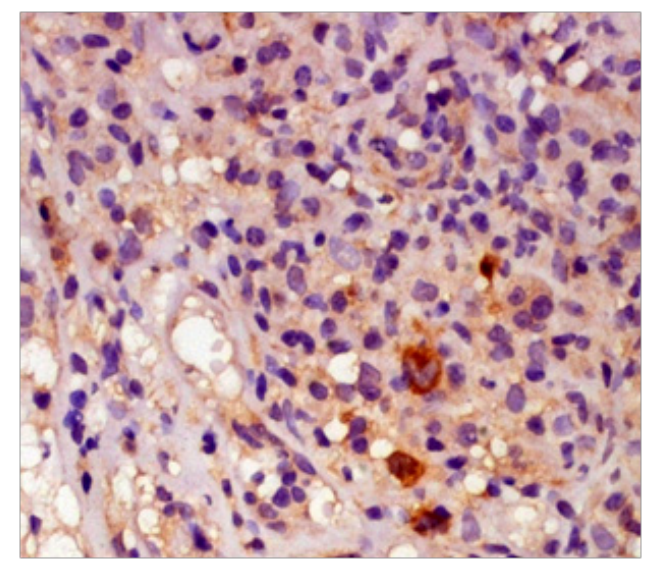

Figure 4 Photomicrograph showing Reed-Sternberg cells staining strongly positive for CD 15.

\section{Discussion}

Patients affected by autoimmune diseases have demonstrated an increased risk of developing lymphoid malignancies. NonHodgkin lymphomas (NHL) have consistently been associated with several autoimmune conditions. Such as, by way of example, rheumatoid arthritis (RA), Sjögren syndrome (SS) and systemic lupus erythematous (SLE). Similarly, even if based on fewer studies, an increased risk of malignant lymphomas has also been associated with celiac disease, dermatitis herpetiformis, Hashimoto's thyroiditis, and autoimmune hemolytic anemia. Epidemiologic analysis by NHL subtype have shown that diffuse large B-cell lymphoma (DLBCL) is more frequently associated with RA and SS, while extra nodal marginal zone lymphoma, in the respective target organs, is strongly associated with SS (Theander et al, 2004) and Hashimoto's thyroiditis. Celiac disease is associated with a 520 -fold increased risk of Entheropathy-associated T-cell lymphoma of the small intestine (EATL). Autoimmune conditions of the skin including psoriasis, pemphigus and discoid lupus erythematous have an increased risk of T-cell cutaneous lymphoma. ${ }^{4}$ Hodgkin's lymphoma has also been associated with some autoimmune conditions, such as RA, SLE and scleroderma (Table 1). ${ }^{5}$

Table I Most frequent histological subtypes associated with singular autoimmune entities and known risk factors. ${ }^{5}$

\begin{tabular}{|c|c|c|}
\hline $\begin{array}{l}\text { Autoimmune } \\
\text { entities }\end{array}$ & $\begin{array}{l}\text { Most frequent } \\
\text { subtype }\end{array}$ & Risk factors \\
\hline $\begin{array}{l}\text { Rheumatoid } \\
\text { arthritis }\end{array}$ & $\begin{array}{l}\text { Diffuse large B- cell } \\
\text { lymphoma }\end{array}$ & $\begin{array}{l}\text { High inflammatory activity, } \\
\text { Male gender }\end{array}$ \\
\hline $\begin{array}{l}\text { Sjögren } \\
\text { syndrome }\end{array}$ & MALT lymphoma & $\begin{array}{l}\text { Low serum immunoglobulin } \\
\text { levels ,High serum } \beta 2 \text { micro } \\
\text { globulin level ,Disappearance } \\
\text { of a positive rheumatoid factor, } \\
\text { Hypocomplementemia, Low } \\
\text { CD4 levels ,Palpable purpura, } \\
\text { parotid gland enlargement }\end{array}$ \\
\hline $\begin{array}{l}\text { Systemic lupus } \\
\text { erythematous }\end{array}$ & $\begin{array}{l}\text { Diffuse large B- cell } \\
\text { lymphoma }\end{array}$ & $\begin{array}{l}\text { Autoimmune hemolytic } \\
\text { anemia ,Leucopenia Chronic } \\
\text { thrombocytopenia Salivary } \\
\text { gland swellings Pulmonary } \\
\text { infiltrates and/or recurrent } \\
\text { pneumonia }\end{array}$ \\
\hline $\begin{array}{l}\text { Hashimoto's } \\
\text { thyroiditis }\end{array}$ & $\begin{array}{l}\text { MALT lymphoma } \\
\text { and diffuse large } \\
\text {,B-cell lymphoma }\end{array}$ & \\
\hline $\begin{array}{l}\text { Systemic } \\
\text { sclerosis }\end{array}$ & B-cell lymphoma & \\
\hline Celiac disease & $\begin{array}{l}\text { Entheropathy-type } \\
\text { Tcell lymphoma }\end{array}$ & Inadequate gluten-free diet \\
\hline $\begin{array}{l}\text { Dermatitis } \\
\text { herpetiformis }\end{array}$ & $\begin{array}{l}\text { Entheropathy-type } \\
\text { Tcell lymphoma }\end{array}$ & Inadequate gluten-free diet \\
\hline
\end{tabular}

AIHA is a recognized complication of lymphoproliferative disorders, especially chronic lymphocytic leukemia. However HL is rarely associated with AIHA. This association was first described by Eisner et al. ${ }^{6}$ The reported frequency of Coomb's Positive hemolytic anemia in adults with HL has ranged from $0.2 \%$ in a large series of 492 from Europe ${ }^{7}$ to 3 and $4 \%$ in two American studies. ${ }^{8}$ When HL is accompanied by AIHA, the hemolysis is usually detected at the time of diagnosis or a relapse. ${ }^{8}$ Very rarely has it been reported to precede the diagnosis of HD, in one case by up to 7years. ${ }^{9,10}$ Immune mediated hemolytic anemia is mostly seen in nodular sclerosing subtype and in mixed cellularity subtypes. ${ }^{3}$ In majority of these patients, AIHA is associated with clinical or pathological evidence of stage III or stage IV disease. The exact mechanism of AIHA in HL is still unclear. ${ }^{1}$ However it may be postulated that the auto antibodies are directly produced by tumor cells or are related to an immune 
regulatory phenomenon. It is possible that there is an autoimmune process at the early stages of HL in which antibodies are produced against the tumor as well as the red blood cells as a Para- neoplastic phenomenon. The antibodies prevent the growth of the tumor at least initially, which later escapes the anti- tumor effect of the antibodies and finally manifests as HL. ${ }^{11}$ Patients with HL are known to have an impaired cell mediated immune response due to increase in number as well as function of T lymphocytes. Decreased number of cytotoxic $\mathrm{T}$ cells could lead to excessive autoantibody production. This appears to be partly due to hyper activation of B-cells. ${ }^{4}$ The other autoimmune manifestations may include the development of neurological disorders, including neuropathies, glomerulonephritis, vasculitis and rarely, arthritis. Taken together these manifestations highlight the prominent relationship between immune dysfunction and HD. ${ }^{12}$

\section{Conclusion}

AIHA is a recognized complication of lymphoproliferative disorders, especially chronic lymphocytic leukemia. HL however is rarely associated with AIHA but should be considered in the presence of warm agglutinin hemolytic anemia. Although the initial treatment of AIHA is steroids, immune haemolysis associated with Hodgkin's disease requires definitive treatment with systemic chemotherapy. Our patient presented with severe AIHA for which no etiology was found at initial presentation. This report illustrates that a patient with AIHA should be carefully investigated particularly in treatment resistant cases for manifestations of HL.

\section{Acknowledgements}

The authors have no conflicts of interests, including specific financial interests, relationships and/or affiliations, relevant to the subject matter or materials included.

\section{Conflict of interest}

The author declares no conflict of interest.

\section{References}

1. Shah MB, Nanjapp V, Devaraj HS, et al. AIHA in Hodgkin's Lymphoma. $J$ Assoc Physicians India. 2013;61(7):492-494.

2. Feng Q, Zak D, Daya R. AIHA and classical Hodgkin's lymphoma: a case report and literature review. Clinical advances in Hematology and Oncology. 2012;10(4):270-276.

3. Ozdemir F, Yilmaz M, Akdogan R, et al. Hodgkin's disease and AIHA: a case report. Medical Principles and Practice. 2005;14(3):205-207.

4. Siddiqui N, Aleem A. AIHA preceding the diagnosis of Hodgkin's disease: A Report of two cases and review of the literature. J Pak Med Assoc. 2009;59(5):316-318.

5. Dolcetti R, Ponzoni M, Mappa S, et al. Autoimmune disorders and lymphomas. Autoimmune Disorders-Pathogenic Aspects. 2011;18:339386.

6. Eisner E, Ley AB, Mayer K. Coomb's positive hemolytic anemia in Hodgkin's disease. Ann Int Med. 1967;66(2):258-273.

7. Xiros N, Binder T, Anger B, et al. Idiopathic Thrombocytopenic pupura and Autoimmune Hemolytic Anemia in Hodgkin's disease. Eur $J$ Haematol. 1988;40(5):437-441.

8. Levine AM, Thornton P, Forman SJ, et al. Positive Coomb's test in Hodgkin's disease: Significance and Implications. Blood. 1980;55(4):607-611.

9. Bowdler AJ, Glick IW. Autoimmune hemolytic anemia as the herald state of Hodgkin's disease. Ann Intern Med. 1966;65(4):761-767.

10. Cazenave JP, Gagnon JA, Girouard E, et al. Autoimmune hemolytic anemia terminating seven years later in Hodgkin's disease. Can Med Assoc J. 1973;109(8):748-749.

11. Garratty G, Petz LD, Wallerstein RO, et al. Autoimmune haemolytic anaemia in Hodgkin's disease associated with anti-It. Transfusion.1974;14(3):226-231.

12. Miller E. Review Hodgkin's Lymphoma and Autoimmunity: A two-way street. Clinical advances in Hematology and Oncology. 2012;10(4):276277. 